\title{
Long-chain Fatty Acid Compositions of Some Asporogenous Yeasts and Their Respective Ascosporogenous States
}

\author{
By BENNIE C. VILJOEN, * JOHAN L. F. KOCK, HENDRIKA B. MULLER \\ AND PIETER M. LATEGAN \\ Department of Microbiology, University of the Orange Free State, PO Box 339, \\ Bloemfontein 9300, South Africa
}

(Received 10 September 1986; revised 10 November 1986)

\begin{abstract}
Long-chain fatty acid compositions were determined for strains of seven species of Candida and their counterparts within the perfect genera: Candida shehatae and Pichia stipitis, Candida kefyr and Kluyveromyces marxianus, Candida lipolytica and Yarrowia lipolytica, Candida pelliculosa and Hansenula anomala, Candida pseudotropicalis and Kluyveromyces fragilis, Candida utilis and Hansenula jadinii, Candida parapsilosis and Lodderomyces elongisporus, Candida shehatae and Pichia stipitis. Close correlations were found between the fatty acid compositions of these pairs of strains, indicating that the analysis of long-chain fatty acids may be useful for studying the relationships between the perfect and imperfect states of the genus Candida.
\end{abstract}

\section{INTRODUCTION}

The genus Candida Berkhout is described by Van Uden \& Buckley (1970) as a heterogeneous collection of asporogenous yeasts which cannot be classified conveniently elsewhere and is gathered for convenience into a single group, based on a few morphological and physiological criteria. The low relatedness observed within this group and the similarities of these imperfect species with the perfect genera Kluyveromyces, Pichia, Hansenula, Yarrowia or Lodderomyces highlighted the diversity of this genus (Leth Bak \& Stenderup, 1969).

Long-chain fatty acid analysis can be a useful tool in the identification and classification of yeasts (Viljoen et al., 1986; Kock et al., 1985). In this study, the long-chain fatty acid compositions of seven species of Candida were compared with those of their supposed teleomorphs.

\section{METHODS}

Strains. Seven Candida species, two species of Kluyveromyces, two species of Hansenula, and one species each of Lodderomyces, Yarrowia and Pichia were used (Table 1).

Cultivation. The stock cultures were maintained on yeast extract/malt extract (YM) (Wickerham, 1951) slants. The yeast strains were cultured for $16 \mathrm{~h}$ at $30^{\circ} \mathrm{C}$ on a rotary shaker at 160 r.p.m. (throw $50 \mathrm{~mm}$ ) in $150 \mathrm{ml}$ Erlenmeyer flasks containing $40 \mathrm{ml}$ medium consisting of glucose (Merck) $\left(80 \mathrm{~g} \mathrm{l}^{-1}\right)$ yeast/nitrogen base $\left(6.7 \mathrm{~g}^{-1}\right)$ (YNB: Wickerham 1951). Then $18 \mathrm{ml}$ of the above culture (Klett reading $150,640 \mathrm{~nm}$ filter) was inoculated into $400 \mathrm{ml}$ glucose/YNB liquid medium in 11 Erlenmeyer flasks and cultured for $2 \mathrm{~d}$ (in order to reach stationary phase) on the rotary shaker. This procedure was repeated three times. The cells were harvested and washed three times with cold saline $(0.85 \% \mathrm{NaCl})$ solution by centrifugation at $8000 \mathrm{~g}$ for $5 \mathrm{~min}$ at $4{ }^{\circ} \mathrm{C}$. The cells were stored at $-15^{\circ} \mathrm{C}$.

Extraction of fatty acids and preparation of methyl esters. The methods of Gunasekaran \& Hughes (1980) were used. The final extraction of the fatty acid methyl esters was performed with the addition of $n$-hexane.

Gas chromatography. The fatty acid methyl esters were analysed and identified by methods described in detail by Viljoen et al. (1986) and Kock et al. (1985).

Numerical analysis. The Pearson product-moment correlation coefficient, $r$, was used to measure the similarity 
Table 1. Mean percentage long-chain fatty acid composition of the strains representing Candida species and their supposed teleomorphs

Values are the means of three repetitions. The standard deviations were about $5 \%$ of the mean value (range 2-6\%). Fatty acids are designated as number of carbon atoms : number of double bonds. UN1 and $U N 2$ represent unidentified fatty acids with retention times of 13.36 and 14.13 min, respectively (retention time for C16:0 10.25 $\mathrm{min}$ ).

\begin{tabular}{|c|c|c|c|c|c|c|c|c|c|c|c|c|}
\hline Strain & Strain no.* & $\mathrm{Cl4:0}$ & $\mathrm{Cl} 14: 1$ & $\mathrm{C} 16: 0$ & $\mathrm{C} 16: 1$ & UN 1 & UN2 & $\mathrm{C} 18: 0$ & $\mathrm{C} 18: 1$ & $\mathrm{C} 18: 2$ & $\mathrm{C} 18: 3$ & $r+$ \\
\hline C. kefyr & CSIR-Y879 & $0 \cdot 1$ & 0.1 & $10 \cdot 1$ & & & _ & & & & & \\
\hline K. marxianus & CBS & $0 \cdot 5$ & $0 \cdot 1$ & 14 & & 0 & 0.5 & & & 1 & .9 & .992 \\
\hline $\begin{array}{l}\text { C. lipolytica }{ }_{+} \\
\text {Y. lipolytica }\end{array}$ & $\begin{array}{l}\text { CBS } 599 \\
\text { Y28 }\end{array}$ & $\begin{array}{l}0 \cdot 1 \\
0 \cdot 1\end{array}$ & $\begin{array}{l}0 \cdot 1 \\
0 \cdot 1\end{array}$ & $\begin{array}{r}12.2 \\
9.9\end{array}$ & $\begin{array}{l}15 \cdot 7 \\
10 \cdot 2\end{array}$ & $\begin{array}{l}0.5 \\
0.1\end{array}$ & $\begin{array}{l}0.9 \\
0.6\end{array}$ & $\begin{array}{l}2 \cdot 0 \\
4 \cdot 0\end{array}$ & $\begin{array}{l}53 \cdot 8 \\
58 \cdot 5\end{array}$ & $\begin{array}{l}14 \cdot 3 \\
16 \cdot 3\end{array}$ & - & 990 \\
\hline $\begin{array}{l}\text { C. pelliculosa } \\
\text { H. anomala }\end{array}$ & $\begin{array}{l}\text { CSIR-Y5 } \\
\text { CSIR-Y605 }\end{array}$ & $\begin{array}{l}0.7 \\
0.8\end{array}$ & & $\begin{array}{l}12 \cdot 3 \\
15 \cdot 5\end{array}$ & $\begin{array}{r}8.8 \\
10 \cdot 0\end{array}$ & $\begin{array}{l}0.9 \\
0.2\end{array}$ & $\begin{array}{l}1.4 \\
0.3\end{array}$ & $\begin{array}{l}4.9 \\
3.5\end{array}$ & $\begin{array}{l}36 \cdot 1 \\
37 \cdot 2\end{array}$ & $\begin{array}{l}27 \cdot 1 \\
27 \cdot 7\end{array}$ & $\begin{array}{l}7 \cdot 3 \\
3 \cdot 1\end{array}$ & 990 \\
\hline $\begin{array}{l}\text { C. pseudotropi- } \\
\text { calis }\end{array}$ & CSIR-Y95 & 0.5 & 0.3 & $12 \cdot 6$ & 13.4 & 0.9 & $0 \cdot 3$ & 3.5 & $27 \cdot 6$ & 31.9 & $9 \cdot 0$ & \\
\hline K. fragilis $\S$ & CBS 1556 & 0.6 & $0 \cdot 3$ & $14 \cdot 3$ & $14 \cdot 5$ & 0.4 & $0 \cdot 1$ & $2 \cdot 1$ & 28.9 & $32 \cdot 7$ & $5 \cdot 9$ & 0.994 \\
\hline $\begin{array}{l}\text { C. utilis } \\
\text { H. jadinii }\end{array}$ & $\begin{array}{l}\text { CBS } 890 \\
\text { CSIR-Y227 }\end{array}$ & $\begin{array}{l}0.7 \\
0.6\end{array}$ & $\begin{array}{l}0.5 \\
0 \cdot 4\end{array}$ & $\begin{array}{l}15 \cdot 2 \\
16 \cdot 3\end{array}$ & $\begin{array}{l}2 \cdot 8 \\
2 \cdot 0\end{array}$ & $\begin{array}{l}0.5 \\
0.3\end{array}$ & $\begin{array}{l}0.6 \\
0.5\end{array}$ & $\begin{array}{l}2 \cdot 3 \\
3 \cdot 2\end{array}$ & $\begin{array}{l}48 \cdot 1 \\
51 \cdot 0\end{array}$ & $\begin{array}{l}26 \cdot 5 \\
23 \cdot 2\end{array}$ & $\begin{array}{l}1.9 \\
2.5\end{array}$ & 0.996 \\
\hline $\begin{array}{l}\text { C. parapsilosis } \\
\text { L. elongisporus }\end{array}$ & $\begin{array}{l}\text { CSIR-Y685 } \\
\text { CSIR-Y162 }\end{array}$ & $\begin{array}{l}0.2 \\
0.2\end{array}$ & - & $\begin{array}{l}11.0 \\
11.9\end{array}$ & $\begin{array}{l}6 \cdot 5 \\
7 \cdot 4\end{array}$ & $\begin{array}{l}0.3 \\
0.7\end{array}$ & $\begin{array}{l}1.7 \\
1.8\end{array}$ & $\begin{array}{l}5 \cdot 3 \\
5 \cdot 2\end{array}$ & $\begin{array}{l}50 \cdot 3 \\
52 \cdot 5\end{array}$ & $\begin{array}{l}20 \cdot 3 \\
19 \cdot 1\end{array}$ & $\begin{array}{l}0.4 \\
0.6\end{array}$ & .998 \\
\hline $\begin{array}{l}\text { C. shehatae } \\
P \text {. stipitis }\end{array}$ & $\begin{array}{l}\text { CSIR-Y493 } \\
\text { CSIR-Y633 }\end{array}$ & $\begin{array}{l}0.9 \\
0.2\end{array}$ & $\begin{array}{l}0 \cdot 1 \\
0 \cdot 1\end{array}$ & $\begin{array}{l}16 \cdot 9 \\
20 \cdot 3\end{array}$ & $\begin{array}{r}9 \cdot 4 \\
10 \cdot 3\end{array}$ & $\begin{array}{l}0.9 \\
0.4\end{array}$ & $\begin{array}{l}1.9 \\
0.5\end{array}$ & $\begin{array}{l}4 \cdot 8 \\
4 \cdot 8\end{array}$ & $\begin{array}{l}36 \cdot 7 \\
36 \cdot 2\end{array}$ & $\begin{array}{l}23 \cdot 8 \\
26 \cdot 2\end{array}$ & $\begin{array}{l}2 \cdot 1 \\
0 \cdot 9\end{array}$ & 9 \\
\hline
\end{tabular}

* CBS, Centraalbureau voor Schimmelcultures, Yeast Division, Delft, The Netherlands; CSIR-Y, cultures obtained from Professor J. P. van der Walt, Pretoria, South Africa.

$+r=$ Pearson product correlation (Pearson \& Hartley, 1958).

$\ddagger$ Now called Yarrowia lipolytica in the CBS catalogue.

$\S$ This strain is now also called Kluyveromyces marxianus in the CBS catalogue.

between any pair of long-chain fatty acids (Pearson \& Hartley, 1958). The product-moment correlation coefficient is defined by the equation

$$
r=\frac{(1 / n) \sum d_{x} d_{y}}{S_{x} S_{y}}
$$

The numerator is the mean product of the deviations of each paired member of the distribution. The denominator $S_{x} S_{y}$ is the product of the standard deviations of the two parts of the yeasts' long-chain fatty acid distributions considered separately.

\section{RESULTS}

Reproducible fatty acid compositions were obtained when the yeast strains were grown in triplicate under standard conditions (Table 1). The 14 species contained palmitic acid (C16:0), palmitoleic acid $(\mathrm{Cl} 6: 1)$, oleic acid $(\mathrm{Cl} 8: 1)$ and linoleic acid $(\mathrm{C} 18: 2)$ as major fatty acids. The following pairs of strains were recognized on the basis of similarities in long-chain fatty acid composition; their characteristic features are summarized.

Candida kefyr and Kluyveromyces marxianus both had a higher mean percentage of palmitoleic acid content than the other species investigated.

Candida lipolytica and Yarrowia lipolytica contained the highest mean percentage of oleic acid, whereas no linolenic acid $(\mathrm{C} 18: 3)$ was detected.

Candida pelliculosa and Hansenula anomala were both characterized by relatively high mean percentages of oleic acid, linoleic acid and linolenic acid.

Candida pseudotropicalis and Kluyveromyces fragilis contained the highest mean percentages of linoleic acid and linolenic acid.

Candida utilis and Hansenula jadinii contained the lowest mean percentages of palmitic acid, oleic acid and linoleic acid.

Candida parapsilosis and Lodderomyces elongisporus contained the highest mean percentage of stearic acid (C18:0), whereas no myristoleic acid (C14:1) was detected.

Candida shehatae and Pichia stipitis contained a higher mean percentage of palmitic acid than the other yeasts studied. 


\section{DISCUSSION}

The genus Candida is composed of species with different morphological, biochemical and ecological characteristics (Montrocher \& Claisse, 1984). This heterogeneity was reflected in the large variation in long-chain fatty acid compositions between the seven Candida species we studied.

Yeasts which produce similar long-chain fatty acids are more closely related than those which differ (Kock et al., 1985; Cottrell et al., 1985; Viljoen et al., 1986). Since all the assumed pairs of perfect and imperfect strains had almost identical long-chain fatty acid compositions (Table 1), these pairings would appear to be correct.

Candida kefyr and Kluyveromyces marxianus produce similar electrophoretic isoenzyme patterns (Sidenberg \& Lachance, 1986) and have similar carbon and nitrogen assimilation profiles (Van Uden \& Buckley, 1970). The similarity in long-chain fatty acid composition between these two yeasts $(r=0.992)$ is in agreement with these results.

Spencer \& Gorin (1969) found that most strains of Candida pelliculosa differed from Hansenula anomala (the supposed ascosporogenous form) since they yielded galactomannans with different proton magnetic resonance spectra. Wickerham \& Burton (1954) found that strains of Candida pelliculosa differed from Hansenula anomala in their physiology. However, Leth Bak \& Stenderup (1969) found close DNA homology between these species. Our data support the latter results since the long-chain fatty acids compositions of these two yeasts were very similar $(r=0.990)$

Candida lipolytica, which has been designated as the imperfect form of the ascosporogenous yeast Yarrowia lipolytica (Diddens \& Lodder, 1939) showed a close relationship $(r=0.990)$, as did Candida pseudotropicalis and its imperfect form Kluyveromyces fragilis $(r=0 \cdot 994)$. Spencer \& Gorin (1969), in agreement with the latter result, found that 'Saccharomyces fragilis' and Candida pseudotropicalis (its presumed imperfect from) formed mannose-containing polysaccharides having identical proton magnetic resonance spectra. ['Saccharomyces fragilis' has since been renamed as Kluyveromyces marxianus var. fragilis Johansen (Sidenberg \& Lachance, 1986; Barnett et al., 1983).] Leth Bak \& Stenderup (1969) also found high DNA homology between Candida pseudotropicalis and Kluyveromyces fragilis.

Candida utilis, which is assumed to be the imperfect form of the ascosporogenous yeast Hansenula jadinii (Lodder \& Kreger-van Rij, 1952), produced long-chain fatty acids similar $(r=0.996)$ to those of its perfect state. Lodderomyces elongisporus is regarded as the ascosporogenous perfect form of Candida parapsilosis (Van der Walt, 1966). Although Meyer \& Phaff (1972) found similar DNA base ratios (39.5-41.2 mol \% G $+\mathrm{C}$ ) between these two yeasts, Montrocher \& Claisse (1984) stated that Lodderomyces elongisporus and Candida parapsilosis differed in their serological and biophysical properties. We found similar long-chain fatty acid compositions $(r=0.998)$ between these two yeasts. A close relationship ( $r=0.994)$ was also found between Candida shehatae and its assumed imperfect counterpart Pichia stipitis (Buckley \& Van Uden, 1967).

The long-chain fatty acid compositions of the Candida species studied coincided with those of their supposed ascosporogenous states. Analysis of long-chain fatty acid composition may therefore prove to be a useful technique for studying the relationships of ascosporogenous and sporogenous yeast species, and may allow the relation between a teleomorph species and its corresponding anamorphic state to be more clearly determined. However, further work is needed on more strains in order to establish the validity of this method.

The authors are indebted to $\mathrm{Mr} \mathrm{P}$. J. Botes for assistance with gas chromatography. We also would like to thank Carol Viljoen for excellent secretarial work.

\section{REFERENCES}

Barnett, J. A., Payne, R. W. \& Yarrow, O. (1983).

Yeasts: Characteristics and Identification. Cambridge \& New York: Cambridge University Press.

BuCkLey, H. R. \& VAN Uden, N. (1967). Candida shehatae sp. n., a yeast associated with wood- destroying insects. Mycopathologia et mycologia Applicata 32, 297-301.

Cottrell, M., Kock, J. L. F., Lategan, P. M., Botes, P. J. \& BRITZ, T. J. (1985). The long-chain fatty acid compositions of species representing the genus 
Kluyveromyces. FEMS Microbiology Letters 30, 373376.

Diddens, H. A. \& Lodder, J. (1939). On some sporogenous yeasts and their imperfect stages. Mycopathologia 2, 28-36.

GunSEKARAN. M. \& HughES, W. T. (1980). Gas-liquid chromatography: a rapid method for identification of different species of Candida Mycologia 72, 505511.

Kock, J. L. F., Lategan, P. M., Botes, P. J. \& ViljoEn, B. C. (1985). Developing a rapid statistical identification process for different yeast species. Journal of Microbiological Methods 4, 147-154.

LeTh BAK, A. \& Stenderup, A. (1969). Deoxyribonucleic acid homology in yeasts. Genetic relatedness within the genus Candida. Journal of General Microbiology 59, 21-30.

LODDER, J. \& KREGER-VAN RIJ, N. J. W. (1952). The Yeasts, a Taxonomic Study. Amsterdam: NorthHolland.

Meyer, S. A. \& PhafF, H. J. (1972). DNA base composition and DNA/DNA homology studies as tools in yeasts systematics. In Yeast, Models in Science and Technics, pp. 375-387. Edited by A. Kochova-Kratochvilova \& E. Minarik, Bratislava: Slovak Academy of Sciences.

Montrocher, R. \& Claisse, M. L. (1984). Biochemical studies in the yeast genus Candida. Cellular and Molecular Biology 30, 291-301.

Pearson, E. S. \& Hartley, H. O. (1958). Biometrika Tables for Statisticians, vol. 1. Cambridge: Cambridge University Press.
Sidenberg, D. G. \& Lachance, M. A. (1986). Electrophoretic isoenzyme variation in Kluyveromyces populations and revision of Kluyveromyces marxianus (Hansen) van der Walt. International Journal of Systematic Bacteriology 36, 94-102.

SPENCER, J. F. T. \& GoRIN, P. A. J. (1969). Systematics of the genus Candida Berkhout: proton magnetic resonance spectra of the mannose-containing polysaccharides of some further species of Candida as an aid in classification. Antonie van Leeuwenhoek 35, 33-44.

VAN DER WaLt, J. P. (1966). Lodderomyces, a new genus of Saccharomycetaceae. Antonie van Leeuwenhoek 32, 1-5.

VAN UdEN, N. \& Buckley, H. (1970). Genus Candida Berkhout. In The Yeasts, a Taxonomic Study, pp. 893-1087. Edited by J. Lodder. Amsterdam: NorthHolland.

Viljoen, B. C., Kock, J. L. F. \& Lategan, P. M. (1986). Long-chain fatty acid composition of selected genera of yeasts belonging to the Endomycetales. Antonie van Leeuwenhoek 52 45-51.

Wickerham, L. J. (1951). Taxonomy of Yeasts. Technical Bulletin No. 1029, United States Department of Agriculture.

Wickerham, L. J. \& Burton, K. A. (1954). A simple technique for obtaining mating types in heterothallic diploid yeasts with special reference to their uses in the genus Hansenula. Journal of Bacteriology 67, 303308 . 